\title{
Off-line Programming and Simulation for 2-axis Wire EDM
}

Saša Živanović

Assistant professor University of Belgrade Faculty of Mechanical Engineering

\section{Radovan Puzović}

Associate professor University of Belgrade Faculty of Mechanical Engineering

\section{INTRODUCTION}

Wire electrical discharge machining (WEDM) is a widely accepted non-traditional material removal process introduced in the late 1960s'. WEDM is a specialized thermal machining process capable of accurately machining workpiece with varying hardness or complex shapes, which have sharp edges and are very difficult to be machined by the other machining processes. The only requirement is that both electrode and workpiece materials are electrically conductive $[1,2]$.

This paper considers off-line programming and simulation of the Wire EDM machine "Ewis" EV.00.000M4, made by Ukrainian company P.O. Novator [3,4], Figure 1. Off-line is a programming method in which the trainer writes a program and uploads it to the machine tool, in this case to the Wire EDM machine.

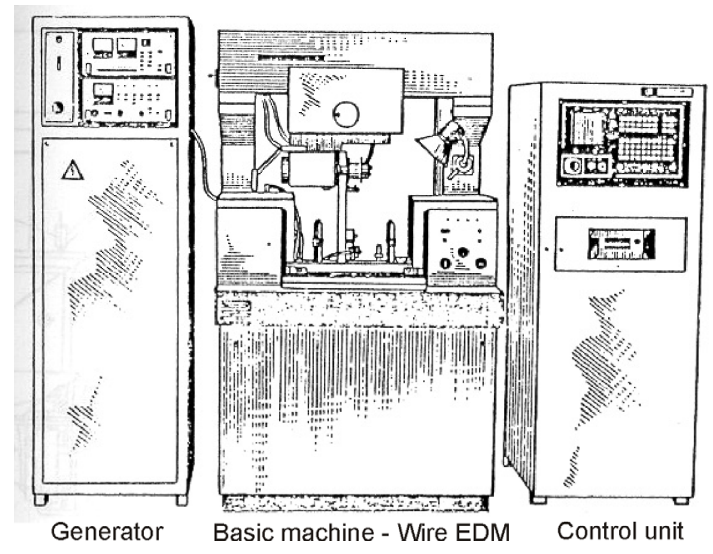

Figure 1. WEDM machine EWIS - PO Novator

Today, there are modern specialized softwares for the off-line programming and simulation for 2 and 4

Received: February 2014, Accepted: July 2014

Correspondence to: dr Sasa Zivanovic

Faculty of Mechanical Engineering,

Kraljice Marije 16, 11120 Belgrade 35, Serbia

E-mail: szivanovic@mas.bg.ac.rs

doi:10.5937/fmet1502138Z

(C) Faculty of Mechanical Engineering, Belgrade. All rights reserved axis Wire EDM solutions [5]. For off-line programming are also applicable CAD/CAM systems like PTC Creo, CATIA, Solid CAM, Machine Simulation PRO [6], and others.

Adequate environment for $\mathrm{CAD} / \mathrm{CAM}$ programming should include: (1) module for modeling or loading the reference models (CAD), (2) module for manufacturing (CAM) to generate toolpaths-CLF, (3) module for postprocessing to obtain $G$ codes, (4) module for toolpath verification and simulation, (5) module for simulation of material removal, and (6) module for machine simulation, which involves the movement of machine parts (machine simulation by running the program). This verification allows the elimination of errors from collisions.

The basic goal is the establishment of adequate CAD/CAM environment for off-line programming and toolpath verification and simulation including the visualization of the machining process, fixture orientation, and machine movements. Chosen environment is CAD/CAM system PTC Creo which allows efficient programming of wire EDM. This paper presents an application of PTC Creo CAD/CAM system that can be achieved via programming, postprocessing, verification program toolpath, simulation of material removal, and verification and simulation of the program (machine simulation with movements of machine parts as a 3D solid model).

The rest of the paper is organized as follows: in Section 2 we present an overview of 2 axis wire EDM; Methodology for off-line programming is described in Section 3; We have developed virtual prototype of WEDM machine Ewis; In Section 4, virtual prototype is used for machining simulation in CAD/CAM system.

\section{OVERVIEW OF 2-AXIS WIRE EDM}

The WEDM process is included in the group of thermoelectric methods since it uses the electrical energy and turns it into thermal energy. During the WEDM process, the material is eroded ahead of the wire and there is no direct contact between the 
workpiece and the wire. This eliminates the mechanical stresses during machining [1]. The material removal mechanism of WEDM involves the erosion effect produced by the electrical discharges (sparks) between the cathode (wire) and anode (workpiece), Figure 2.

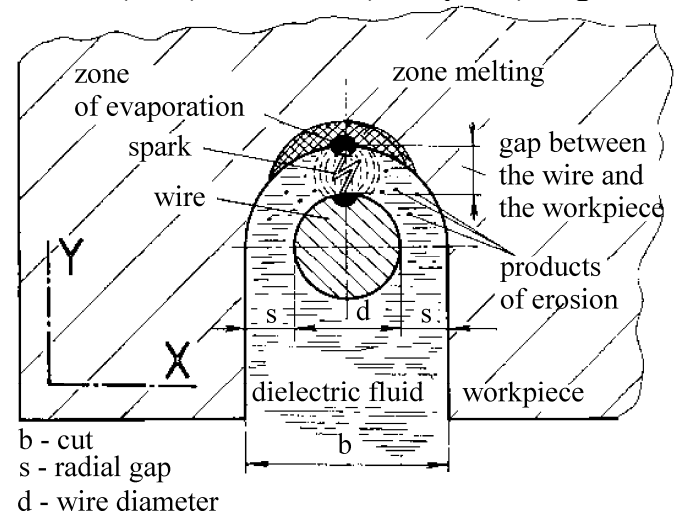

Figure 2. Principle of Wire EDM process [7]

This process is commonly conducted on workpieces that are totally submerged in a tank filled with dielectric fluid. Electricity leads to the appearance of sparks between the electrodes (wire and workpiece), creating high temperature concentrated on a small surface of the material. Workpiece includes zones of evaporation, and melting of the workpiece material.

The WEDM process generates thermal energy at the temperature range between $8000-12000{ }^{\circ} \mathrm{C}$ [8]. One portion of the materials is melted and removed by dielectric fluid jet. Jet of dielectric fluid, constantly passing through the erosion area removes products of erosion and cools down both electrodes.

The movement of wire is controlled numerically to achieve the desired two-dimensional shape and accuracy of the workpiece. The detailed section of the working region of the WEDM cutting is shown in Figure 3. WEDM utilises a continuously travelling wire electrode made of thin copper, brass, or tungsten with diameter $0.05-0.3 \mathrm{~mm}$.

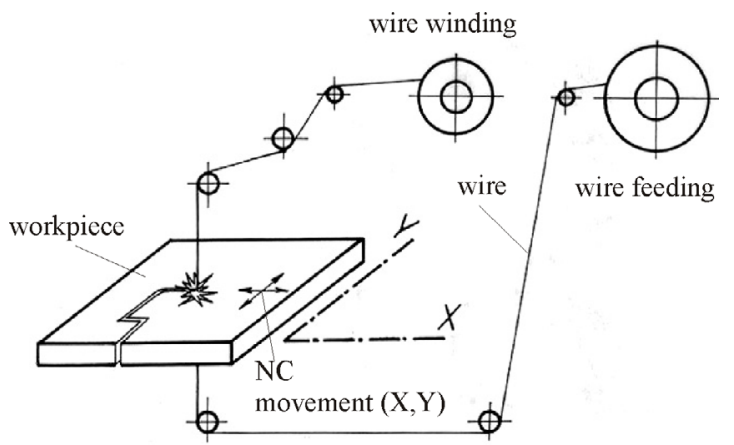

Figure 3. Scheme of WEDM cutting [7]

Verification of programs for WEDM machine is achieved by graphic simulation prior to the execution of the program on the machine. This verification is carried out by execution of the program on the machine without technology, drawing the programmed paths on the paper. Because of this kind of program verification, the application of off-line programming method becomes more important.

WEDM machine that is the subject of this study is shown in Figure 1. Its basic units are: basic machine -
Wire EDM, control unit, and generator. WEDM machine, from Figure 1, is fully modelled in Creo CAD/CAM system in order to complete the system for off-line programming and verification program. In addition to verification of simulation wire path, the machining simulation of the complete machine model is included.

\section{METHODOLOGY FOR OFF-LINE PROGRAMMING}

With the use of a postprocessor to convert CL file into $\mathrm{G}$ code, programming is very conventional. .Postprocessing is done in the same way as for the 2axis contouring machining. Off-line programming methodology will be described using IDEF0 diagrams. IDEF0 is a method designed to model the decisions, actions, and activities of an organization or system. It is useful in establishing the scope of an analysis, especially for a functional analysis [9]. IDEF0 is used to produce a "function model". A function model is a structured representation of the functions, activities, or processes within the modelled system or subject area. This paper describes the function of Wire EDM off-line programming and simulation, using the IDEF0 diagram. The special case of one-box IDEF0 context diagram, containing the top level function being modelled along with its inputs, controls, outputs, and mechanisms is shown in Figure 4.

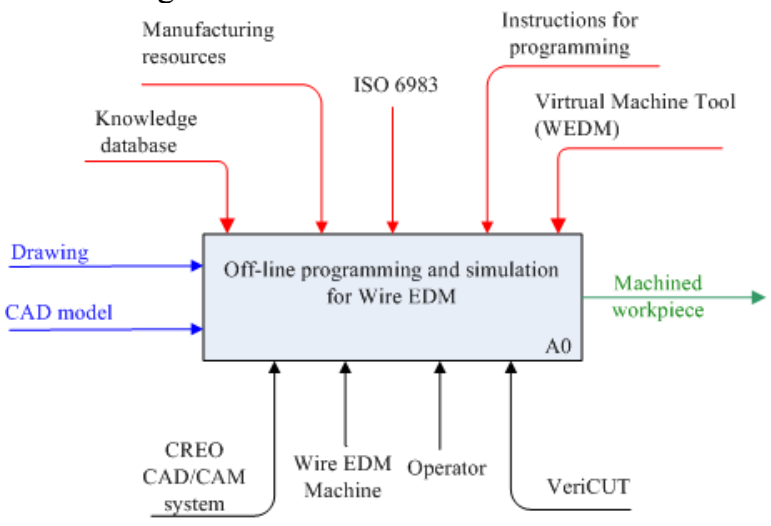

Figure 4. Top-level IDEF0 daiagram for off-line programming and simulation for Wire EDM

Inputs for off-line programming can be drawings or CAD model, while the output is machined workpiece. Based on these inputs, preparing reference models for the off-line programming, wire path, and $G$ code are obtained. Verification of $G$ code is carried out by using toolpath simulation, material removal simulation, and machine simulation. WEDM machine Ewis, is programmed in $G$ code according to the standard ISO6983. The single function represented on the toplevel context diagram may be decomposed into its major sub-functions by creating its sub-diagrams. Each subdiagram contains the sub-boxes and arrows that provide additional details about the parent box. The sub-diagram that results from the decomposition of a function covers the same scope as the parent box it refers to. According to the IDEF0 methodology, by analyzing A0 diagram, we obtain the basic flow of activities shown in Figure 5. The basic activities are: A1 - CAD, A2 - CAM, A3 Postprocessors, A4 - Wire path verification, and simulation A5 - Machining. 


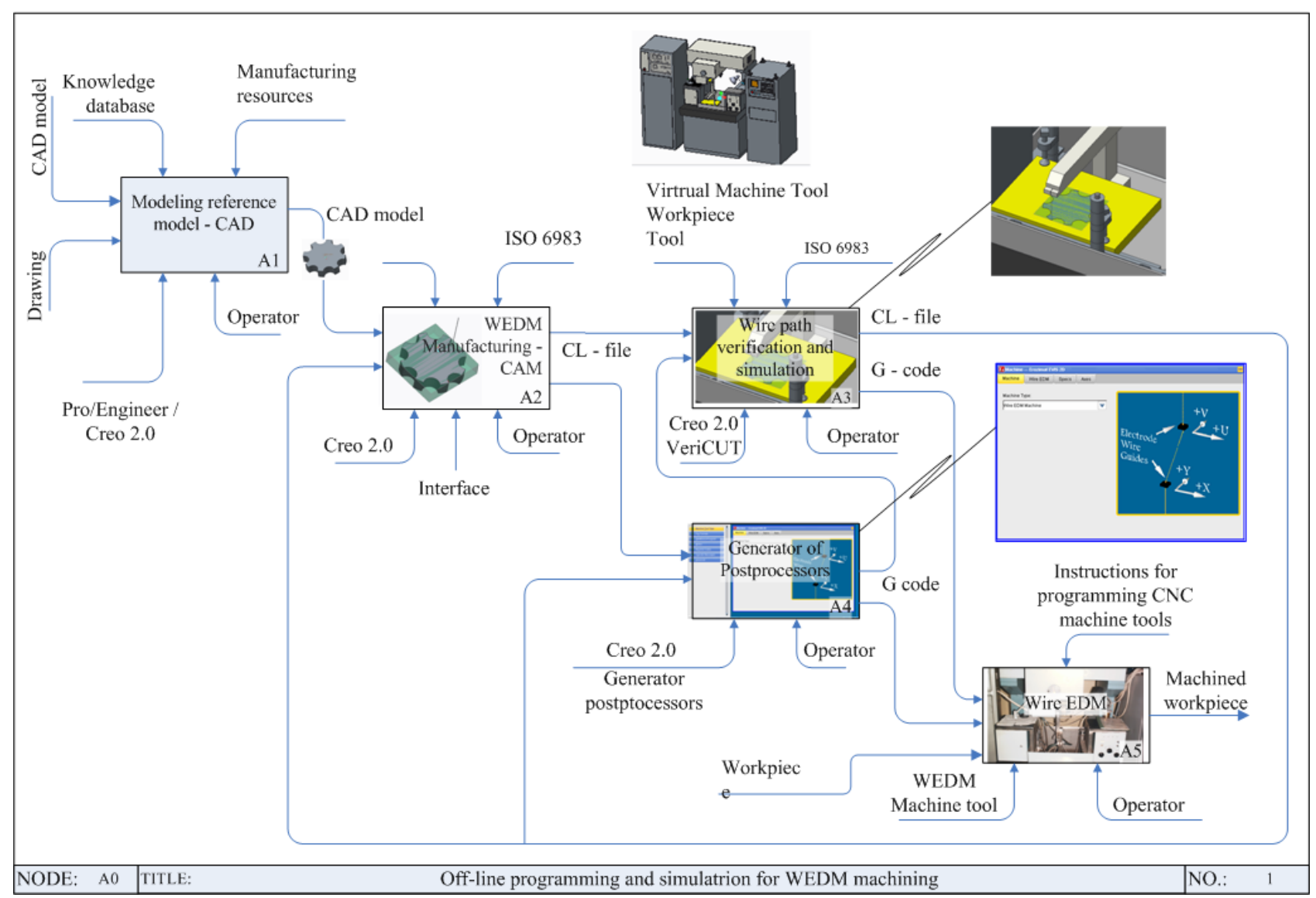

Figure 5. Basic flow of activities for off-line programming and simulation for WEDM

Inputs for activity A1 are drawing or CAD model, that creates reference model for activity A2 (WEDM manufacturing - CAM). When the output from activity A2 is obtained (CL-file), it is verified within activity A3 using wire path simulation, material removal simulation, and machine simulation. If some errors and collision are identified during the simulation, the activity $\mathrm{A} 2$ repeats until the verification of CL file. Verified CL-file goes to the postprocessing activity in the A4. Postprocessor is configured using the postprocessor generator in the $\mathrm{CAD} / \mathrm{CAM}$ system Creo. In this case we used 2-Axis Wire EDM NC sequences for any type of 2-axis contour machining, including Wire EDM. Obtained G code can be forwarded to the activity A3 to verify the wire path or can be forwarded directly to the machine. After verification of the program in $\mathrm{G}$ code, one can safely pass over to the activity A5, where the machining is achieved on Wire EDM, without additional testing that exists on the machine.

\section{MACHINE SIMULATION}

Machine simulation by running the program is possible due to the application of machine mechanism modelling with all kinematic connections between components. This allows the motion of virtual model as a system of rigid bodies. Figure 6 shows a detailed virtual model of WEDM machine mechanism with all kinematic relationships between moving components being defined. Conection slider is used for the movement of two sliders $(\mathrm{X}, \mathrm{Y})$.
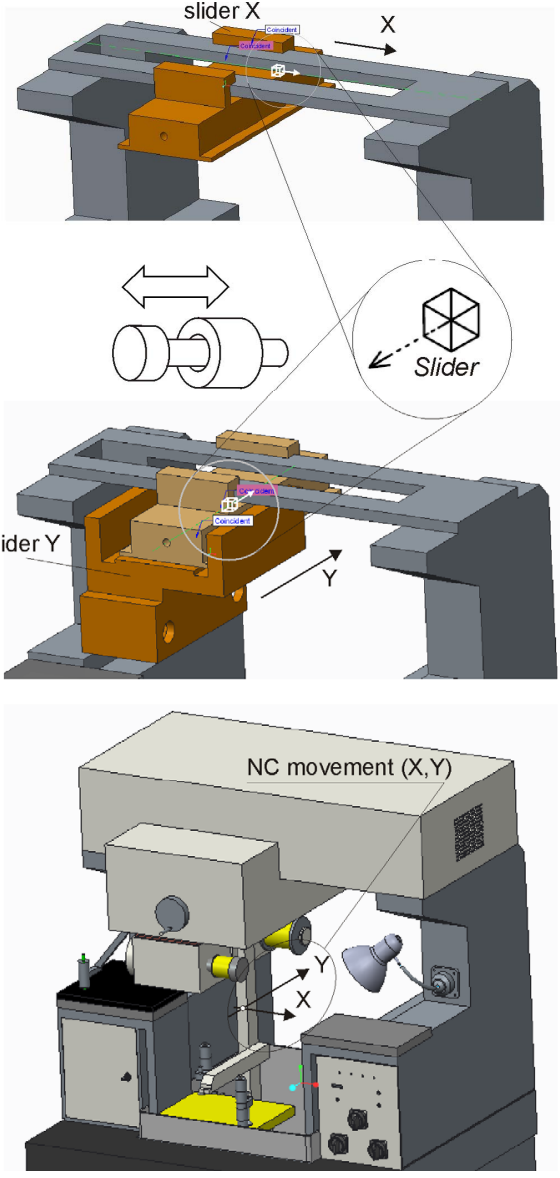

Figure 6. Virtual model for the simulation of mechanism kinematics 
This assembly enables the motion of models in the range defined for each connection, that is of particular importance for the identification of possible collisions during the work of mechanism. Machining simulation of virtual model allows motion of movable segments, with the wire at the end. On the screen, one can see the wire path which is a result of the execution program, obtained by programming using PTC Creo CAD/CAM system. The machine is programmed in the format of the program, which is based on the $\mathrm{G}$ code.

We should pay attention when setting up a workpiece, which must be within the limits of the machine workspace. If the workpiece is not within the workspace, the error will occur because the tool can not achieve the programmed trajectory.

Based on the drawing from Figure 7, the reference CAD model is modelled that was used to verify off-line programming for 2-axis Wire EDM.

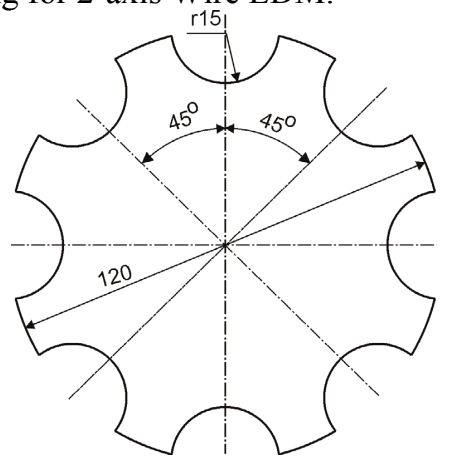

Figure 7. Workpiece used to verify off-line programming

For the reference CAD model shown in Figure 8a, we have set up the zero point in the center, with the coordinate axes $\mathrm{X}, \mathrm{Y}, \mathrm{Z}$, and it was marked as MACH_ZERO.
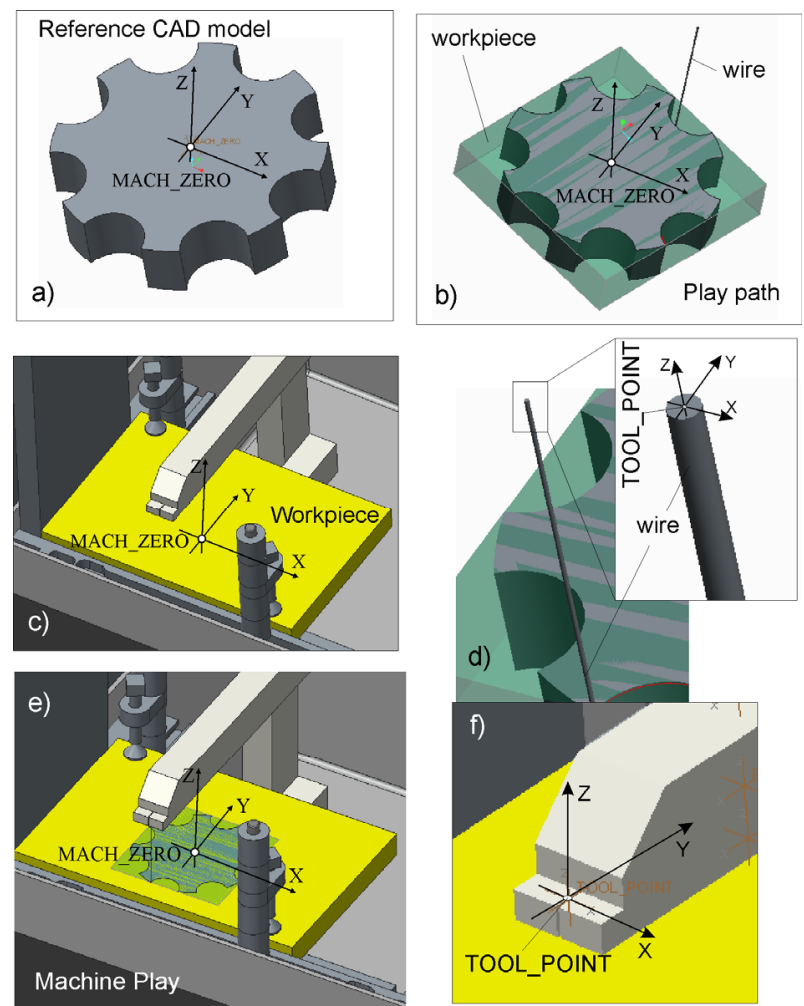

Figure 8. Coordinate system of the workpiece and tool with tool path simulation
The identical zero point (MACH_ZERO) exists on the WEDM machine workpiece (Figure 8c). Matching of these two coordinate systems is done by setting the workpiece on the machine during the machining simulation.

Figure $8 \mathrm{~b}$ presents the simulated wire path on the workpiece, based on the generated CL file. Tool coordinate system is defined in the same way as workpiece coordinate system and it is shown in Figure $8 \mathrm{~d}$. On the machine, tool coordinate systems are marked as a TOOL_POINT (Figure 8f). Matching of the tool coordinate system on the tool (wire) and on the machine results in the setting of the tool (wire) into the machine during the simulation process. Successful simulation is possible if the kinematic connections are correctly defined, as shown in Figure 6.

WEDM machine Ewis [2] was set up at the Faculty of Mechanical Engineering (University of Belgrade), Figure 9.

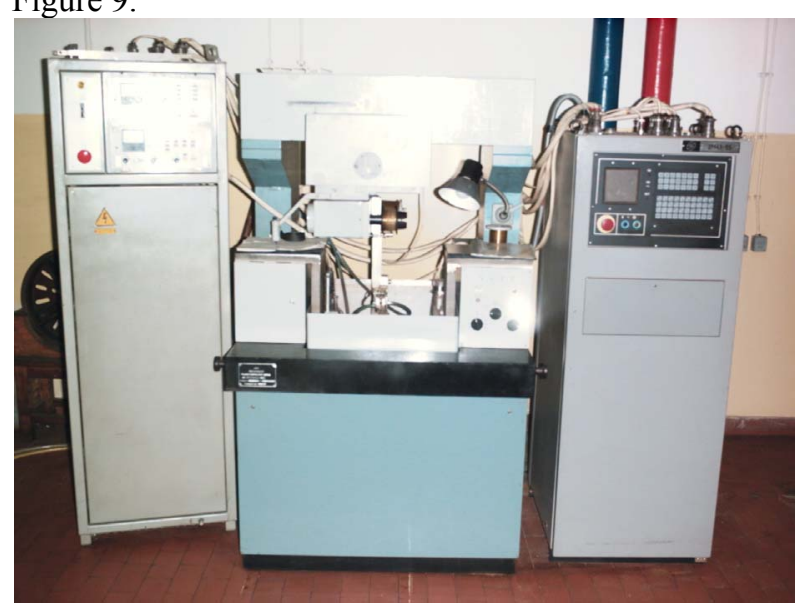

Figure 9. WEDM machine EWIS, PO Novator

WEDM machine in Figure 9 is fully modelled in CAD/CAM environment (PTC Creo), with all kinematics joints, in order to be able to include virtual machine model to machine simulation (Figure 11). Upon the programming completion, verification of the CL-file is achieved by simulating the wire tool path (Figure 10).

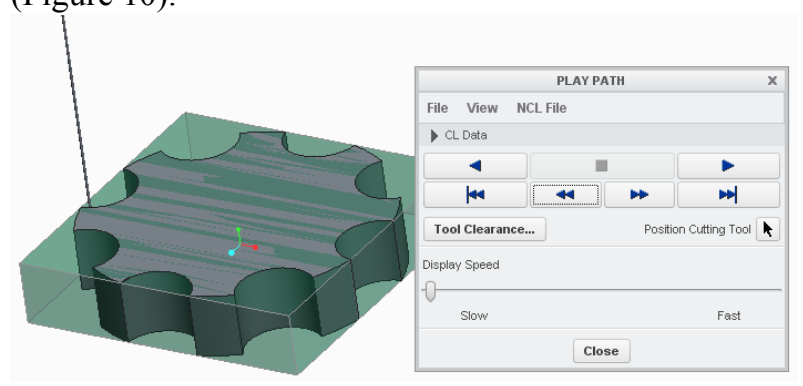

Figure 10. Wire path verification and simulation in Creo 2.0 (Play path)

During the wire path simulation, complete CAD model of virtual machine can be included into the simulation, with Machine play option, in CAD/CAM system PTC Creo. The completed wire path simulation can be simulated by using rendered solid model of the machine, including fixtures and workpiece. Example of verification by machining simulation in the CAD/CAM system PTC Creo is shown in Figure 11. 


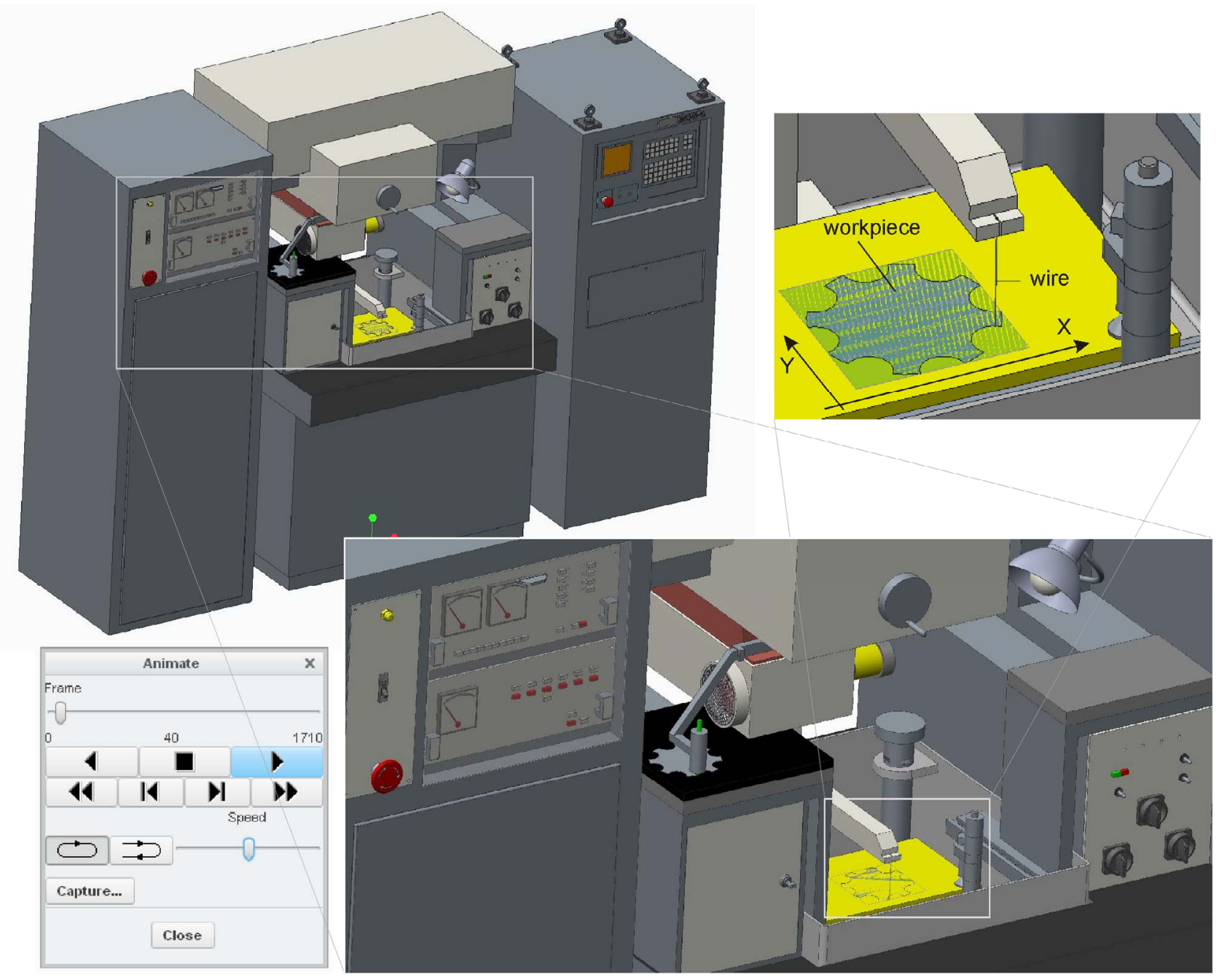

Figure 11. 3D solid simulation of Wire EDM machining in Creo 2.0

After the simulation process is completed, the postprocessing follows. The special postprocessor needs to be configured for WEDM machine Ewis by using the postprocessor generator from the CAD/CAM system PTC Creo. G code for a given WEDM machine is specific in a way that the coordinates $\mathrm{X}$ and $\mathrm{Y}$ are in microns. The parts of $\mathrm{G}$ code and wire path in NC Plot V1.2 editor [10] are shown in Figure 12.

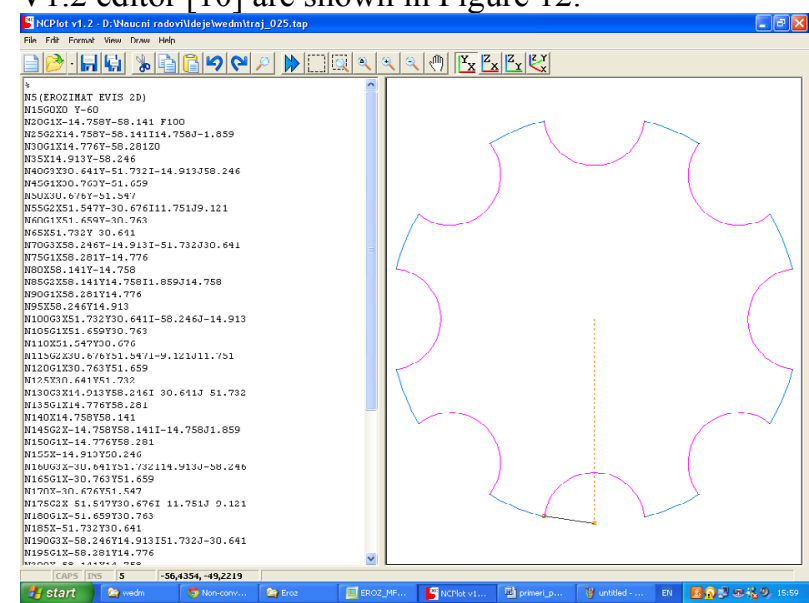

Figure 12. G code and wire path in NC Plot V1.2

The machining result of the example from Figure 7, on WEDM machine Ewis, is shown in Figure 13.
Figure 13 shows a comparative view of the workpiece and the resulting waste material as a CAD model (Figure 13a) and a real machined part (Figure 13b). The contour of the workpiece was cut in steel sheet with $3 \mathrm{~mm}$ thickness.

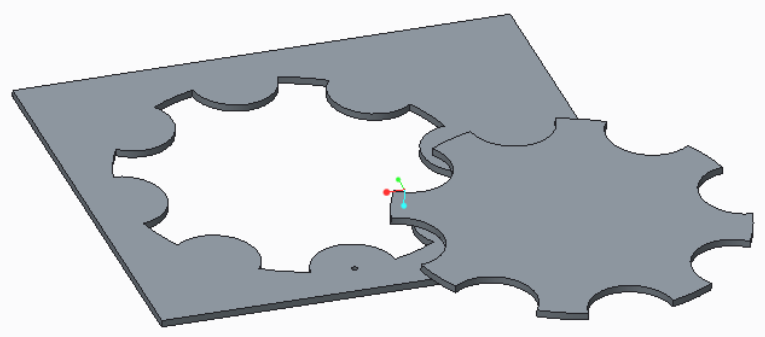

a) CAD model of workpiece and waste material

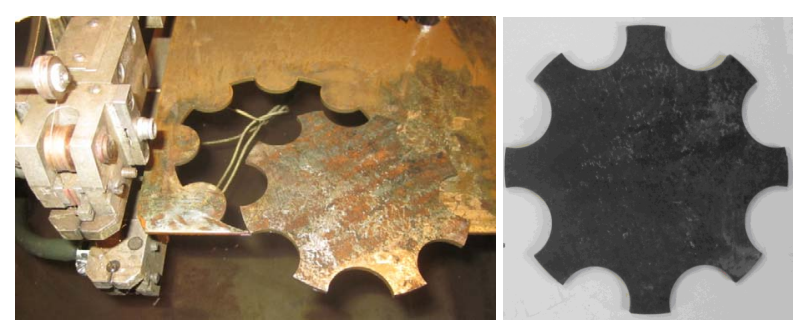

b) Machined workpiece

Figure 13. Result of machining 


\section{CONCLUSION}

This paper presents methodology for successful establishing of environment for off-line programming within a CAD/CAM system that enables wire tool path simulation, material removal simulation, and machine simulation involving the movement of machine parts. Chosen environment that fully meets all requirements is PTC Creo.

At present, machining simulation plays an important role in modern manufacturing, and this paper presents an integration of the off-line programming and machine simulation in CAD/CAM system Creo. Verification program is established by machining simulation in $\mathrm{CAD} / \mathrm{CAM}$ system, where the machine is working by the running program.

Off-line programming and simulation is very important for increasing the level of programming and program verification for WEDM machine Ewis. Until now programs for this WEDM machine were tested by graphical simulation on the same machine. Graphical simulation uses a pen to draw contour of the wire toolpath. Off-line programming allows multiple verification programs, and after this verification program is immediately executed on the machine. Further research needs to be related to the applicability of the new method of programming known as STEP-NC $[11,12]$, for WEDM.

\section{ACKNOWLEDGMENT}

The author would like to thank the Ministry of Science and Technological Development of Serbia for providing financial support that made this work possible.

\section{REFERENCES}

[1] Ho, K.H., Newman, S.T., Rahimifard, S. and Allen, R.D.: State of the art in wire electrical discharge machining (WEDM), International Journal of Machine Tools \& Manufacture, Vol. 44, pp. 12471259, 2004.

[2] Sanchez, J. A., Plaza, S., Lopez de Lacalle L. N., and Lamikiz, A.: Computer simulation of wireEDM taper-cutting. International Journal of Computer Integrated Manufacturing, Vol. 19, No. 7, pp. $727-735,2006$.

[3] ЭВИС, Станок электроэрозионный вырезной ЧПУ, П.О. Новатор, ЭВ 00.000 М4.

[4] Базовое обеспечение устроиства числового программного управљения на базе микро ЭВМ, Руководство оператера, 00143-02 34 01, листов 75, ПО Новатор, 1988.

[5] PEPS Wire EDM, Advanced 2 and 4 axis Wire EDM solutions, http://www.peps.com/brochures
[6] Bob CAD/CAM Machine Simulation Pro, http://bobcad.com/products/machine-simulation-pro/

[7] Zivanovic, S.: Choise of machining data and technology for electrodischarge cutting, in: Proceedings of the 23th JUPITER Conference, 1997, Faculty of mechanical Engineering, Belgrade, pp. 293-298, (in Serbian).

[8] Boothroyd, G., and Winston, A.K.: Nonconventional machining processes, Fundamentals of Machining, Marcel Dekker, Inc, 1989.

[9] Kim, S.H. and Jang, K.J.: Designing performance analysis and IDEF0 for enterprise modelling in BPR, International Journal of Production Economics, Vol. 76, No.2, pp. 121-133, 2002.

[10] NC Plot, http://www.ncplot.com

[11] Erdos, G. and Xirouchakis, P.: STEP-NC data model development for Wire-EDM manufacturing, IFAC Inteligent Manufacturing Systems, pp. 51-56, 2003.

[12]Zivanovic S. and Glavonjic M.: Simulations of machining based on STEP-NC, in: Proceedings of the 11th Anniversary International Conference on Accomplisments in Electrical and Mechanical Engineering and Information Technology DEMI 2013, 30.05-01.06.2013, University of Banja Luka, Faculty of Mechanical Engineering, pp. 513-521.

\section{OFF-LINE ПРОГРАМИРАЊЕ И СИМУЛАЦИЈА ДВООСНЕ ЕЛЕКТРОЕРОЗИОНЕ ОБРАДЕ СА ЖИЦОМ}

\section{Саша Живановић, Радован Пузовић}

У раду је представљена методологија за успостављање off-line система за програмирање са верификацијом путање алата и симулацијом која укључује визуелизацију процеса обраде, оријентацију прибора и померања машине. Ова методологија је описана помоћу IDEF0 дијаграма и разрађена помоћу PTC Creo CAD/CAM система. У раду је приказан моделирани детаљни виртуелни прототип машине Евис, са дефинисаним свим кинематичким везама између покретних делова, како би било могуће укључити виртуелни модел машине у симулацију. Off-line програмирање омогућава вишеструку верификацију програма, после које се програм може одмах извршавати на машини. Off-line програмирање је верификовано на реалном примеру верификацијом и извршењем програма за његову обраду. 